\title{
An inter-comparison of model-simulated east-west climate gradients over South Africa
}

\author{
Mark R Jury* \\ University of Zululand, KwaDlangezwa, 3886, South Africa \\ Physics Department, University of Puerto Rico Mayaguez, PR, USA 00681
}

\begin{abstract}
This study examines how the east-west gradient of climate over South Africa is represented in terms of mean rainfall, tropospheric humidity and circulation, and surface latent heat flux in the satellite era 1980-2001. Inter-comparisons of NCEP2 reanalysis and GPCP satellite-gauge merged rainfall with coupled general circulation model (GCM) simulations from generic CMIP-3 are made, with a focus on the maize belt $25^{\circ}-29^{\circ} \mathrm{S}, 25^{\circ}-30^{\circ} \mathrm{E}$. The summer climatology is analysed for the zonal gradient in vertical atmospheric structure and the annual cycle of rainfall. A wet bias is found in most simulations over the eastern mountains, but in two GCMs (CSM3, PCM) it extends over the western plateau. The east-west gradient in vegetation affects the vertical flux of surface moisture into the atmosphere. ECMWF reanalysis and SAFARI-2000 flux tower data reveal that this process is triggered during daytime heating, so model ability to handle the diurnal cycle is crucial. Inter-annual variability is briefly studied and two operational ensemble models (CFS and ECHAM4) simulate and forecast summer rainfall variations with positive correlation to observed values. The AIRS satellite night and day relative humidity structure is contrasted for dry and wet January months. All five generic CMIP-3 models: GFDL2, CSM3, PCM, HADen, ECHAM4 project a drying trend in the maize area over the period 2000-2050, using the SRES A1B scenario. Recommendations for observing the surface and mixed layer moisture fluxes are given.
\end{abstract}

Keywords: east-west climate gradient, model simulation and intercomparison, South Africa

\section{Introduction}

Understanding and predicting South African climate is challenging because of the sharp east-west moisture gradient over the subtropical plateau (Hulme et al., 1996). As a food-exporting nation, South Africa's maize production is highly sensitive to summer (December to February) rainfall anomalies: varying from an area-averaged 1 to $4 \mathrm{t}$ /ha (Schulze et al., 1993; Martin et al., 2000). Much of the rainfall comes from tropical-temperate troughs that induce NW-oriented cloud bands across the eastern Kalahari savanna (Barclay et al., 1993). The annual rainfall cycle peaks in January as the inter-tropical convergence zone dips south-eastward. External forcing of South Africa's climate comes through the Pacific El Niño Southern Oscillation (ENSO) and regional changes in SE Atlantic / SW Indian Ocean sea surface temperatures (SST) and winds (Mason and Jury, 1997).

Coupled general circulation models (GCM) have shown skill in simulating the distribution and variability of rainfall and temperature over Southern Africa (Barnston et al., 2003). The subcontinent creates zones of convergence through orographic friction, thermally-induced circulations and evapotranspiration (cf. surface fields in Fig. 1). Soil moisture and latent heat flux are useful determinants of the surface water budget and potential for agriculture (Delworth and Manabe, 1989; Poveda et al., 2001; Atlas et al., 1993; Poveda et al., 2005). Southern Africa is of sufficient scale to be represented in general circulation models (GCMs) of $2^{\circ}$ resolution, for landsurface feedbacks with atmospheric convection to be evaluated.

\footnotetext{
* To whom all correspondence should be addressed.

I +1321 6930674; e-mail: mark.jury@upr.edu

Received 11 April 2010; accepted in revised form 27 June 2012.
}

Furthermore, climatologies over South Africa's maize belt will benefit from a well-maintained and dense observing system (Fig. 1b)

Model-simulated rainfall distributions are related to pathways between moisture sources and sinks over oceans and continents (Misra et al., 2002). While moisture is sourced from warm seas, lifting mechanisms are more vigorous in mountain locations during summer heating. Typically, mean rainfall declines westward across subtropical continents, but a poor representation of this gradient over South Africa may arise through the way interactions are handled between the warm humid air mass off the east coast, mid-tropospheric subsidence, the seasonally-alternating zonal circulation and surface fluxes. Research is needed to assess model ability to simulate rainfall and other climatic variables over South Africa's maize belt by inter-comparison with satellite-gauge merged products and observation-based reanalyses. Prospects for improved long-range forecasts partially depend on how well the earth system feedbacks are represented, and the ability of monitoring and modelling tools to quantify the initial state and external forcing.

Here the ability of GCMs to simulate and predict the South African summer circulation and east-west moisture gradient is assessed. The main focus is on representation of the climatology rather than forecasts or projections. Comparative work can be found in Tadross et al. (2005), Christensen et al. (2007), and Engelbrecht (2009). Answers are sought to the following questions: How well do GCMs simulate the zonal overturning circulation that is critical for summer water balance? How do satellite-gauge merged and reanalysis estimates of mean rainfall compare with GCMs? Are GCM rainfall biases related to tropospheric circulations, surface fluxes, or systematic model errors? What is the amplitude of diurnal and synoptic forcing in dry and wet summers? And, how can this information be 

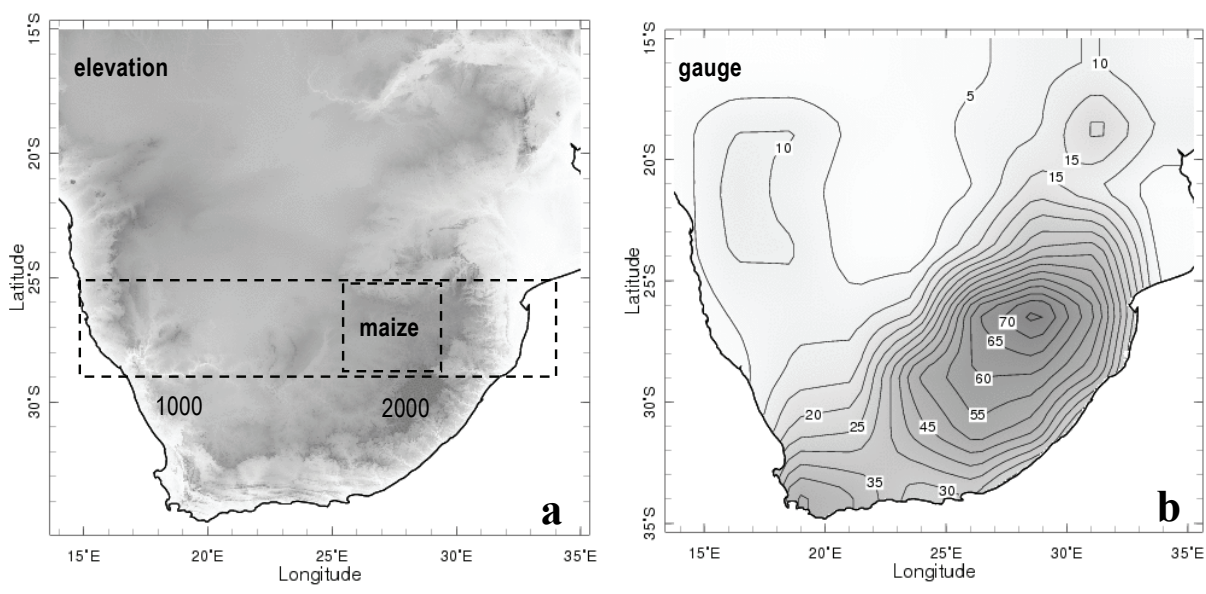

Figure 1

(a) Topography of southern

Africa shaded 0-2000 m white to grey with boxes

used in the analysis,

(b) GPCP gauge

density $/ 100 \mathrm{~km}$ averaged

1979-2007. (c) MODIS

maximum land surface
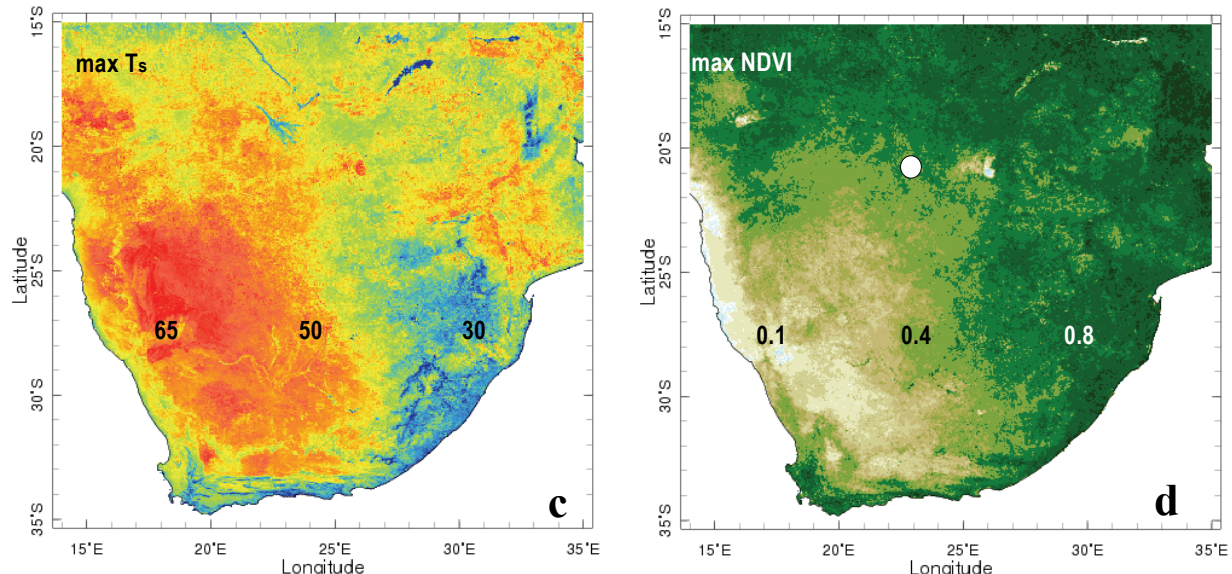

temperature in 2009 shaded

orange $\left(65^{\circ} \mathrm{C}\right)$ to blue

$\left(30^{\circ} \mathrm{C}\right)$ and $(\mathrm{d})$ maximum

vegetation fraction in 2009

shaded white (0.1) to green

(0.8). White dot in $(d)$ is

location of covariance

flux measurement

(cf. Fig. 4 c, d).

used to plan field campaigns and improve operational climate predictions for South Africa? The paper's structure includes an account of 2 verification and 6 model products; followed by results divided into: summer climatology, annual rainfall cycle, surface fluxes, past inter-annual variability and projected climate trends; and, finally, conclusions.

\section{Verification and modelling products}

This section provides a brief description of each product, most of which are drawn from the IRI climate library website (http://iridl.ldeo.columbia.edu/ ...with the GCM data using the extension... SOURCES/.WCRP/.CMIP3/). The domain considered is $15^{\circ}-35^{\circ} \mathrm{S}, 14^{\circ}-35^{\circ} \mathrm{E}$, with a focus on the band $25^{\circ}-29^{\circ} \mathrm{S}$, between $25^{\circ}-30^{\circ} \mathrm{E}$ (Fig. 1a); the maize belt of South Africa, which extends from Bloemfontein and Gaborone in the west, to Pretoria and Pietermaritzburg in the east. The time period selected to produce climatologies is January 1980 to December 2001, and coincides with the satellite era when version2 National Center for Environmental Prediction (NCEP) reanalysis begins and the third Coupled Model Intercomparison Project (CMIP-3) historical runs end. All data employed in this analysis are monthly gridded averages. The surface (non-rainfall) fields include Moderate Imaging Spectrometer (MODIS) satellite estimated surface temperature (Ts) and vegetation fraction (normalized difference vegetation index, NDVI), and Climate Prediction Center (CPC) soil moisture reanalysis (Fan and Van den Dool, 2004). The surface latent heat flux $(Q e)$ is a model output that quantifies the rate of surface water vaporisation and vertical transport by turbulent mixing. The simplest approach is to estimate $Q e$ from a bulk formulae which depends on wind speed and the vertical gradient of specific humidity at the surface. Over land, vegetation transmits vapour into the lower atmosphere by transpiration. Attention is given to this process by analysis of diurnal changes in European Community Medium-range Weather Forecasts (ECMWF; Uppala et al., 2005) latent heat fluxes and roughness length and comparison with Variable Infiltration Capacity (VIC) model surface fluxes (Sheffield et al. 2006). Direct measurements of surface latent heat flux were obtained from flux towers in the central savanna as part of the SAFARI-2000 Kalahari transect (Scanlon and Albertson, 2004; Lloyd et al., 2004). $Q e$ fluxes were measured by fast response vertical gust and specific humidity covariance ( $w^{\prime} q$ ') sensors every 30 min during February-March 2000. This site (Maun, Botswana) has a vegetation fraction consistent with South Africa's maize belt.

Seasonal area-averaged rainfall is estimated by merged gauge and satellite radiance data (Huffman et al., 2007), and by model physics and dynamics in NCEP2 reanalysis. The satellite-gauge merged product uses 3-hourly geostationary infrared brightness temperatures to define the duration of 'cold' clouds, then utilises the passive microwave cloud water emission and the Global Precipitation Climatology Project (GPCP) local gauge data to generate a monthly precipitation estimate at $1^{\circ}$ grid (Adler et al., 2003). The NCEP2 reanalysis (Kanamitsu et al., 2002) uses the operational Climate Data Assimilation System in a physics/dynamics-based numerical weather prediction model (MRF) with a resolution of $\sim 200 \mathrm{~km}$. The database includes surface station, radiosonde, aircraft and satellite sources. Rainfall is model-calculated in the ArakawaSchubert convective parameterisation scheme that depends on water vapour flux convergence, among other factors. Satellitederived vegetation colour maps (NDVI), Atmospheric Infra-red Sounding (AIRS) night and day-time relative humidity vertical 
sections (from disc.sci.gsfc.nasa.gov/giovanni), and NCEP wind anomalies are studied for contrasts between dry and wet January months, when climatic conditions are most critical for maize growth (Jury et al., 1997a). Synoptic weather effects are described using hovmoller plots of smoothed daily MODIS Ts, GPCP rainfall and NCEP 925-700 mb zonal wind combined with $700-500 \mathrm{mb}$ vertical motion averaged over $25-29^{\circ} \mathrm{S}$ for the $15-34^{\circ} \mathrm{E}$ longitudes in the October-April months of 2002-03 (dry) and 2005-06 (wet).

GCM climatologies available as part of CMIP-3 were computed from historical runs in the period 1980-2001 from: GFDL2.1, PCM, CSM3, HADen, and ECHAM4. In addition, NCEP's operational coupled climate forecast system (CFS) ensemble runs were analysed for climatic features of interest. The CMIP-3 models have been comprehensively reviewed in Meehl et al. (2005), Meehl et al. (2007), and Reichler and Kim (2008). The Geophysical Fluid Dynamics Lab model (GFDL2) is described by Delworth et al. (2006), Gnanadesian et al. (2006) and Griffies et al. (2006) and is close to the CMIP-3 ensemble mean (Meehl et al., 2007). The resolution of its land and atmospheric components is $2^{\circ} \times 2.5^{\circ}$; the atmospheric model has 24 vertical layers; the ocean model resolution is $<1^{\circ}$, with 50 vertical layers (MOMv3). Version 2.1 of the GFDL model has improved representation of clouds and land surface forcing. The National Center for Atmospheric Research Parallel Climate Model (PCM) is described by Washington et al., (2000). It has a spatial resolution of 2.8 degrees, 26 vertical levels in the troposphere, and shallow convection is parameterized according to Hack (1994). The boundary layer is modelled according to Holtslag and Boville (1993) and considers the soil physics and vegetation. The ocean model has a grid $<1^{\circ}$, with 40 vertical levels and its dynamics are based on Large et al. (1994). The Community Climate System Model (here CSM3) of NCAR has $\sim 120 \mathrm{~km}$ resolution (Collins et al., 2006; Chang et al., 2007). Deser et al. (2006) point out that the CSM3 has regional biases that affect rainfall, mainly through the strength of the subtropical anticyclones and continental monsoons. The CSM3 has improved cloud processes, aerosol radiative forcing, land-atmosphere fluxes and ocean-mixed layer processes that produce stable simulations. The Hadley GEM1 ensemble model (here: HADen) is described by Johns et al. (2006) and Martin et al. (2006) and has a $1.25^{\circ}$ latitude x $1.87^{\circ}$ longitude resolution with 38 vertical layers. It is non-hydrostatic, clouds and convection are parameterised, and the boundary layer scheme is from Lock (2000). The vegetation is static and the ocean model is derived from Gordon et al. (2000). The hydrology scheme is based on Cox et al. (1999). The ECHAM4 GCM is based on the ECMWF atmospheric model and parameterisation schemes developed at Max Planck Institute for Meteorology which allows the model to be used for coupled climate simulations. The INGV version is a spectral transform model with 19 atmospheric layers and spatial resolution of about $2.8^{\circ}$ latitude and longitude. A summary of developments regarding ECHAM4 model physics is given in Roeckner et al. (1996). The initial SST is from NOAA; terrain heights are extracted at high resolution. The vegetation fraction is based on the Wilson and Henderson-Sellers (1985) data, and the model is said to handle the diurnal cycle and mountain-drag. The ECHAM4 ocean model is updated from Oberhuber (1993). The Climate Forecast System (CFS) is a coupled dynamical seasonal prediction system operational at NCEP (Saha et al., 2006) that is not part of CMIP-3. The atmospheric component of the CFS is a $\sim 180 \mathrm{~km}$ resolution version of the Global Forecast System used for daily numerical weather prediction.

\begin{tabular}{|l|l|c|}
\hline \multicolumn{2}{|c|}{$\begin{array}{c}\text { Table 1 } \\
\text { Description of gridded climate observations and model } \\
\text { products designated as: } \\
\text { ^ models of generic CMIP-3 type, } \\
\text { mof operational forecast type, and * models of } \\
\text { both CMIP-3 and operational. }\end{array}$} \\
\hline & $\begin{array}{l}\text { Description } \\
\text { Neso- } \\
\text { lution }\end{array}$ \\
\hline $\begin{array}{l}\text { NDVI } \\
\text { max Ts }\end{array}$ & $\begin{array}{l}\text { Satellite vegetation and surface tem- } \\
\text { perature from MODIS }\end{array}$ & $10 \mathrm{~km}$ \\
\hline GPCP & $\begin{array}{l}\text { Global Precipitation Clim. Project } \\
\text { blended satellite-gauge data }\end{array}$ & 100 \\
\hline NCEP2^ & $\begin{array}{l}\text { Version 2 hindcast assimilation by } \\
\text { MRF atmospheric model }\end{array}$ & 180 \\
\hline GFDL2* & $\begin{array}{l}\text { Geophysical Fluid Dynamics Lab. } \\
\text { GCM version 2.1 }\end{array}$ & 200 \\
\hline PCM & $\begin{array}{l}\text { NCAR Parallel Climate } \\
\text { GCM }\end{array}$ & 280 \\
\hline CSM3* & $\begin{array}{l}\text { NCAR Community Climate System } \\
\text { GCM version3 }\end{array}$ & 120 \\
\hline HADen & Hadley Center GCM ensemble run & 180 \\
\hline ECHAM4* & $\begin{array}{l}\text { European Community Max Planck } \\
\text { GCM version4.5 }\end{array}$ & 280 \\
\hline CFS^ & $\begin{array}{l}\text { NCEP’s operational coupled climate } \\
\text { ensemble forecast model }\end{array}$ & 180 \\
\hline
\end{tabular}

\begin{tabular}{|c|c|c|c|c|c|}
\hline \multicolumn{6}{|c|}{$\begin{array}{c}\text { Table } 2 \\
\text { Correlation coefficients of operational model simulation } \\
\text { (0-lead), forecast (3-lead) and observed (NCEP2, } \\
\text { GPCP) December-February rainfall over South Africa } \\
\text { in the period 1980-2007 (cf. Fig. 4e, f). Bold values are } \\
\text { significant above } 90 \% \text { confidence limit. }\end{array}$} \\
\hline 0 -lead & CSM3 & ECHAM & GFDL & CFS & NCEP2 \\
\hline ECHAM & 0.10 & & & & \\
\hline GFDL & 0.50 & 0.33 & & & \\
\hline CFS & 0.03 & 0.65 & 0.53 & & \\
\hline NCEP2 & -0.12 & -0.07 & 0.34 & 0.26 & \\
\hline GPCP & 0.05 & 0.18 & -0.09 & 0.13 & 0.65 \\
\hline 3-lead & CFS & ECHAM & & & \\
\hline ECHAM & 0.54 & & & & \\
\hline GPCP & 0.22 & 0.27 & & & \\
\hline
\end{tabular}

The ocean component is the GFDL MOMv3. A set of coupled retrospective ensemble forecasts is made at different lead times back to 1981 using assimilated observations as in reanalysis. Here the shortest lead time of 15 days is used to simulate climatological rainfall, whilst 3-month lead times are evaluated for inter-annual forecasts. The CMIP-3 models used in the climatology and trend analyses are listed in Table 1. As a separate study of inter-annual variability, rainfall simulations and forecasts from operational ensemble versions of a similar group of GCM were analysed from the IRI climate library website, with extension: /SOURCES/.IRI/.FD/. These are initialised using operational boundary conditions and persisted SST, as distinct from the long-term runs of CMIP-3. The operational models used to evaluate seasonal forecasts (cf. Figs. 4e, f) are listed in Table 2.

\section{Data analysis}

Rainfall fields for NCEP2, GPCP, and 6 GCMs were evaluated for the mean annual cycle over the $25^{\circ}-29^{\circ} \mathrm{S}$ latitude of South Africa, and plotted as a longitude-time hovmoller from 1 July, to emphasize the east-west gradient and summer 
maximum. January mean NCEP2 zonal winds, vertical motion and relative humidity for the $25^{\circ}-29^{\circ} \mathrm{S}$ latitude were analysed as a vertical section across the longitudes $15^{\circ}-34^{\circ} \mathrm{E}$ from $1000-300 \mathrm{mb}$ overlying a topographic profile that reaches $800 \mathrm{mb}$. The circulation data are combined into zonal wind and vertical motion (UW) vectors with W exaggerated 100fold. For comparative purposes, the graphics use consistent scaling. To study surface feedbacks, latent heat fluxes were intercompared. Model performance was evaluated for specific features: amplitude and displacement of the annual cycle of rainfall, the east-west gradient and depth of relative humidity, the zonal overturning circulation (lower easterlies lifted to join upper westerlies), and the east-west gradient of surface latent heat flux. To reduce the influence of product resolution on the outcome, all fields were re-gridded to $100 \mathrm{~km}$ resolution and graphical smoothing was applied. Inter-annual variability was assessed by extracting December to February rainfall departures in the maize area over the 1980-2007 period, in both simulation (0-lead) and forecast mode (3-month lead). Crosscorrelations were computed between the GCM and observed time series; with $N=28$ the $90 \%$ confidence limit is reached when $r>0.30$. To study climate change, GCM projections of annual soil moisture in the maize area were extracted from the CMIP-3 database for the period 2001-2050 using the A1B global emissions scenario (Nakicenovic and Swart, 2000) and compared with a circulation index calculated from standardised departures of the $850 \mathrm{mb}$ easterly wind and $600 \mathrm{mb}$ vertical motion. A linear trend was fitted to the multi-model mean and its statistical significance was evaluated.

\section{Results}

\section{Vertical section and annual cycle simulation}

The ability of models to simulate the January mean structure of relative humidity and the tropospheric circulation along an east-west cross-section is evaluated in Fig. 2, together with the mean annual cycle of rainfall. Considering the results modelby-model, starting with NCEP2, it is found that a strong gradient exists in atmospheric moisture. Relative humidity is $>75 \%$ east of $30^{\circ} \mathrm{E}$ below $850 \mathrm{mb}$. In the maize area the January value is $63 \%$ and a steady gradient of $5 \%$ per $100 \mathrm{~km}$ occurs, such that west of $23^{\circ} \mathrm{E}$ the $850 \mathrm{mb}$ relative humidity (RH) is $<40 \%$. This structure extends upward to $600 \mathrm{mb}$, so the isolines over the central plateau are rather vertical. The top of the moist layer, where $\mathrm{RH}>50 \%$, is $\sim 600 \mathrm{mb}$ in the maize area. The tropospheric circulation reveals weak inflow toward the eastern mountains, but little zonal flow below $800 \mathrm{mb}$ over the central plateau. Upper westerlies strengthen above $600 \mathrm{mb}$ in January. The annual cycle of rainfall in NCEP2 hindcast reaches a maximum of $4.6 \mathrm{~mm} /$ day over the eastern mountains in January, with a westward extension of $2 \mathrm{~mm} /$ day to $25^{\circ} \mathrm{E}$. Over the maize area the rainfall is $3.4 \mathrm{~mm} /$ day with an eastwest gradient of $\sim 0.5 \mathrm{~mm} /$ day per $100 \mathrm{~km}$. The NCEP2 patterns serve as a reference for GCM-simulated structure.

The CSM3 structure departs from NCEP2 wherein the east-west gradient of relative humidity and rainfall are poorly represented: the Kalahari is too wet in late summer. The isolines of RH slant over the Kalahari rather than being vertical, and uplift extends too far west in the $500 \mathrm{mb}$ layer in the CSM3 January climatology. In comparison, the GFDL2 simulation has a more realistic vertical structure for $\mathrm{RH}$, but is too wet over the maize area, RH at $850 \mathrm{mb}$ is $79 \%$ compared with $63 \%$ with that of NCEP2, and January mean rainfall is $6.1 \mathrm{~mm} /$ day: about
1.8 times NCEP2. The tropospheric circulation in the GFDL2 simulation reveals that low level easterlies are deep and extend too far west over the Kalahari. Hence the rainfall spreads westward in the annual cycle: $4 \mathrm{~mm} /$ day reaches $21^{\circ} \mathrm{E}$. The ECHAM4 simulation has good RH structure in comparison with NCEP2, although the moist layer $(\mathrm{RH}>50 \%)$ is too deep over the maize area. The tropospheric circulation is well represented, but uplift over the eastern mountains is too strong and as a result, rainfall there $\left(30^{\circ} \mathrm{E}\right)$ reaches $7.5 \mathrm{~mm} /$ day, 2.2 times the NCEP2 value. Like the GFDL2 climatology, ECHAM4 rainfall spreads too far west over the Kalahari: $>4 \mathrm{~mm} /$ day at $22^{\circ} \mathrm{E}$. The HADen simulation of RH structure is quite close to NCEP2 in terms of vertical isolines and moist layer height, but, like ECHAM4, uplift is too strong over the eastern mountains and consequently January rain rates exceed $8 \mathrm{~mm} /$ day at $30^{\circ} \mathrm{E}$, the highest of all GCM considered here. At least the Kalahari is drier, with summer rainfall $<3 \mathrm{~mm} /$ day in the HADen simulation. The PCM model shares similar problems with CSM3 in the low-level easterlies simulated too far west; so the annual cycle of rainfall peaks in February in the Kalahari $\left(20^{\circ} \mathrm{E}\right)$. The CSM3 RH structure has isolines slanting downward to the west rather than vertical, but the moist layer is relatively shallow and rain rates over the maize area are close to NCEP2. The deficiency is in the zonal overturning circulation being located too far west in the PCM simulation.

\section{Annual cycle climatology and surface fluxes}

Rainfall climatology observed by GPCP (Fig. 3a) is close to NCEP2, the maximum $>4 \mathrm{~mm}$ /day spreads across the eastern mountains and the east-west gradient is $0.5 \mathrm{~mm} /$ day per $100 \mathrm{~km}$. The maize area receives $3.4 \mathrm{~mm} /$ day in agreement with NCEP2. The main difference is that GPCP observations indicate a westward spread of rainfall from early to late summer more than NCEP2, such that the $2 \mathrm{~mm}$ /day isoline reaches $23^{\circ} \mathrm{E}$ in February. The GPCP summer rainfall gradient over the Kalahari is even, whereas the NCEP2 gradient is tighter (weaker) east (west) of $25^{\circ} \mathrm{E}$. The CFS rainfall simulation (Fig. 3b) is too wet over the eastern mountains, peaks too early (November instead of January) and the east-west gradient is too strong in the maize belt. CMIP-3 GCM rainfall generally peaks too early: December instead of January.

Considering the surface feedbacks, Fig. $3 \mathrm{c}$ illustrates the annual cycle climatology for CPC soil moisture. The maximum is reached in late summer (February-March) over the eastern mountains following orographic rains. The east-west gradient of soil moisture is 14 to $8 \mathrm{~mm}$ across the maize area. Marked east-west gradients in boundary layer height are evident in Fig. 3d. The CFS model climatology simulates a large annual cycle for mixed layer height, with a maximum of $1600 \mathrm{~m}$ over the Kalahari $\left(20^{\circ}-25^{\circ} \mathrm{E}\right)$ in early summer (NovemberDecember) prior to heaviest rains.

Intercomparison of surface latent heat flux may determine why some models better simulate the east-west gradient of rainfall over South Africa. This element is often modelderived; direct observations are rare. The NCEP2 January mean fluxes (Fig. 4a) go from $35 \mathrm{~W} / \mathrm{m}^{2}$ in the west to about $100 \mathrm{~W} / \mathrm{m}^{2}$ over the eastern mountains. The ECMWF fluxes have a similar structure, but are slightly lower across South Africa except in the eastern mountains $29^{\circ}-30^{\circ} \mathrm{E}$. The GFDL and ECHAM4 simulated January mean latent heat fluxes are closest to reanalysis in terms of slope and value: $\sim 10 \mathrm{~W} / \mathrm{m}^{2}$ high in the maize area. The CFS and HADen models also replicate the slope, but values are $>20 \mathrm{~W} / \mathrm{m}^{2}$ above reanalysis in 

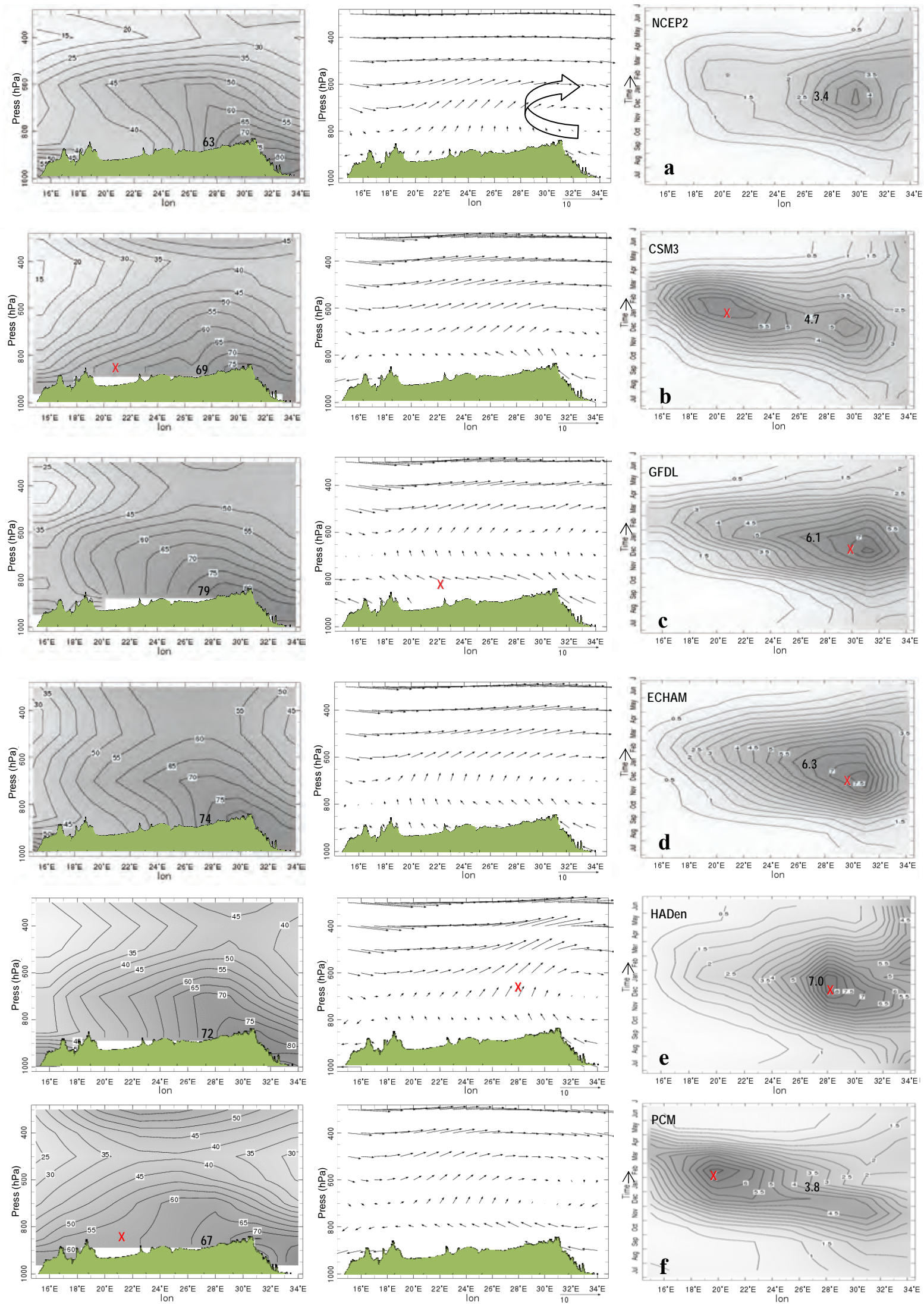

Figure 2

January climatology as vertical east-west section averaged $25^{\circ}-29^{\circ} \mathrm{S}$ for relative humidity shaded $10-90 \%$ white to grey (left) and zonal wind and vertical motion represented as vector with $W$ exaggerated 100-fold (middle), and annual cycle climatology hovmoller for rainfall ( $\mathrm{mm} /$ day) averaged over same latitudes (right) for (a) NCEP, (b) CSM3,

(c) GFDL, (d) ECHAM, (e) HADen, (f) PCM models for the period 1980-2001. Arrow in (a) highlights the zonal overturning cell, small red crosses identify unrealistic features, bold numbers are January values in the maize area. 

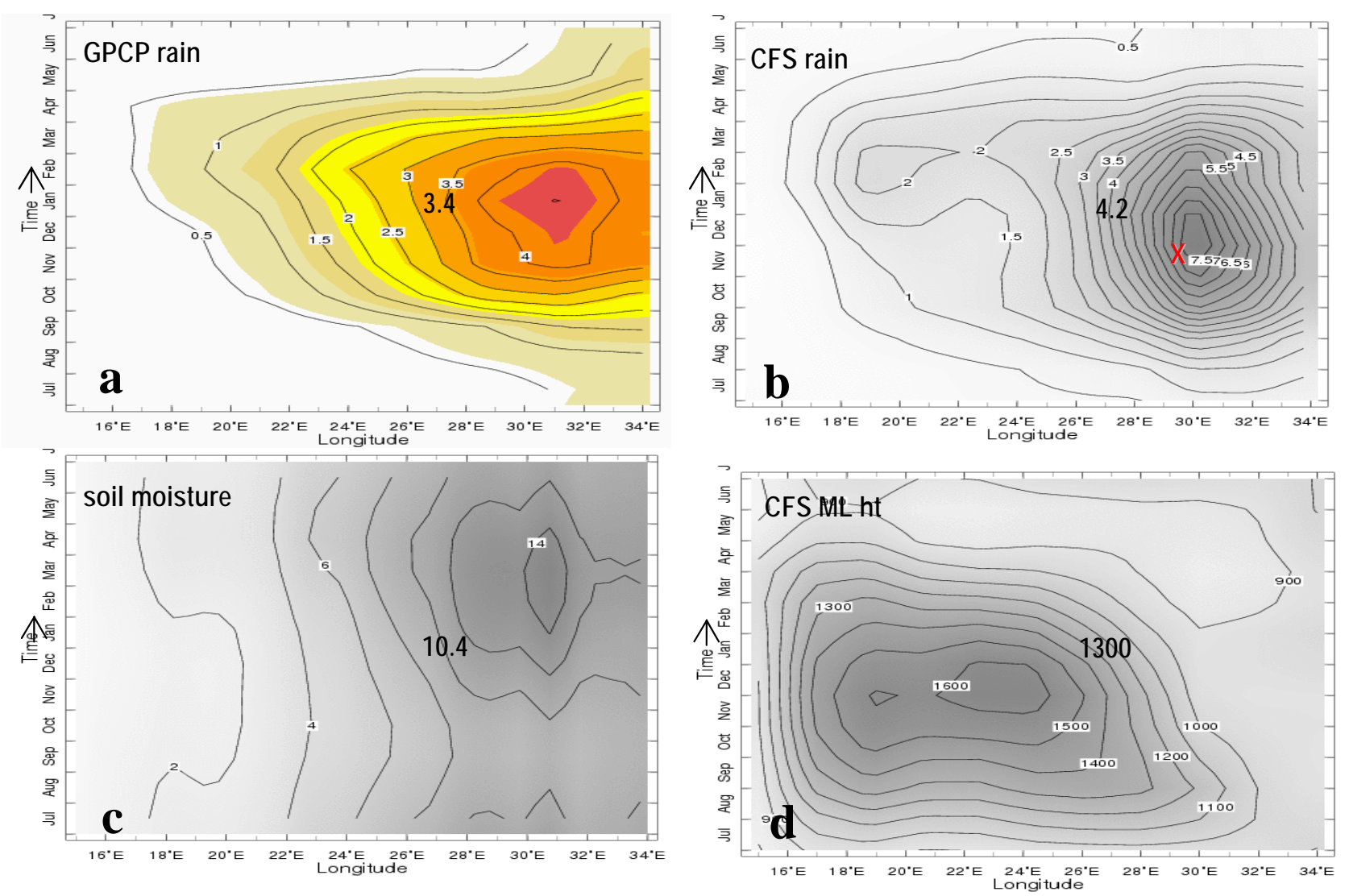

Figure 3

Annual cycle climatology hovmoller averaged $25^{\circ}-29^{\circ} \mathrm{S}$ for (a) GPCP satellite-gauge rainfall (coloured as validation), (b) CFS model rainfall (both $\mathrm{mm} /$ day), (c) CPC soil moisture reanalysis ( $\mathrm{mm}$ ), and (d) CFS mixed layer height $(m)$. Red cross identifies unrealistic feature, bold numbers are January values in the maize area.

the maize area. Both CSM3 and PCM simulated January mean latent heat fluxes have little slope, being $>50 \mathrm{~W} / \mathrm{m}^{2}$ too high in the west and too low in the east. This may contribute to the aforementioned wet bias over the Kalahari.

Analysing factors governing the east-west climate gradient, the diurnal amplitude of surface moisture fluxes is seen to be important. Daytime ECMWF surface latent heat fluxes increase steeply toward the east (Fig. 4b), while night time fluxes are near zero and exhibit little east-west gradient (flat slope). The January mean VIC model evapotranspiration $\left(\mathrm{W} / \mathrm{m}^{2}\right)$ lies between the two profiles and follows the nearlinear upward slope of satellite-derived vegetation (NDVI) from 0.06 at $15^{\circ} \mathrm{E}$ to 0.67 at $32^{\circ} \mathrm{E}$. The ECMWF model surface roughness quantifies the frictional drag of topographic undulations and vegetation cover. Roughness is a constant $0.1 \mathrm{~m}$ over the Kalahari and rises to $1.2 \mathrm{~m}$ across the eastern mountains. Direct measurements from Maun, Botswana are given in Fig. 4c and Fig. 4d for latent heat flux covariance during February- March 2000. Qe varies from 0 at night to $>300 \mathrm{~W} / \mathrm{m}^{2}$ in the daytime. Its mean diurnal cycle reaches $200 \mathrm{~W} / \mathrm{m}^{2}$ at solar noon, a value consistent with ECMWF fluxes in Kalahari longitudes $\left(20^{\circ}-25^{\circ} \mathrm{E}\right)$. Cross-correlation of 70 meteorological parameters with measured Qe reveals strong control by solar radiation $(r=94 \%, N=2880)$ and consequently surface temperature, but no immediate association with rainfall. Chikoore and Jury (2010) demonstrate a multi-week delay between a rain event, greening of vegetation and subsequent infusion of moisture to the atmospheric mixed layer. Area-averaged NCEP2 flux estimates at the Maun site are
$>60 \mathrm{~W} / \mathrm{m}^{2}$ too high (Fig. $4 \mathrm{~d}$ ), mainly during night and morning hours. Extrapolating this short set of direct observations to places with similar vegetation $(\sim 0.6)$ and soil moisture such as the maize belt (cf. Figs. 1d, 3c) suggests that modelled fluxes are reasonable. Further model improvements such as dynamic vegetation in CMIP-5 (Taylor et al., 2011) should better constrain the associated feedbacks.

\section{Representation of climate variability and trends}

Intercomparisons of operational ensemble model simulated and forecast time series of DJF rainfall over the maize area from 1980 to 2007 are given in Figs. 4e and 4f and cross-correlations are listed in Table 2 . While simulation data sets are readily available, ensemble forecast products (initialised with operational boundary conditions and persisted SST) are more limited. This set of model runs, available through the IRI forecast division website, must be seen as distinct from generic CMIP-3 simulations that are unrelated to observed conditions. The cross-correlations indicate that many operational models fail to adequately capture the inter-annual rainfall variability over South Africa's maize area. Only the operational ECHAM4 and CFS ensemble model outputs have positive but weak correlation $>10 \%$ with GPCP rainfall, and only the operational GFDL has a positive significant correlation with NCEP2 reanalysis. The two verification products, NCEP2 and GPCP, show good agreement (Table 2). At 3-month lead time the operational CFS and ECHAM4 model summer rainfall cross-correlations with GPCP rainfall are positive but weak. The 1980-2007 time 

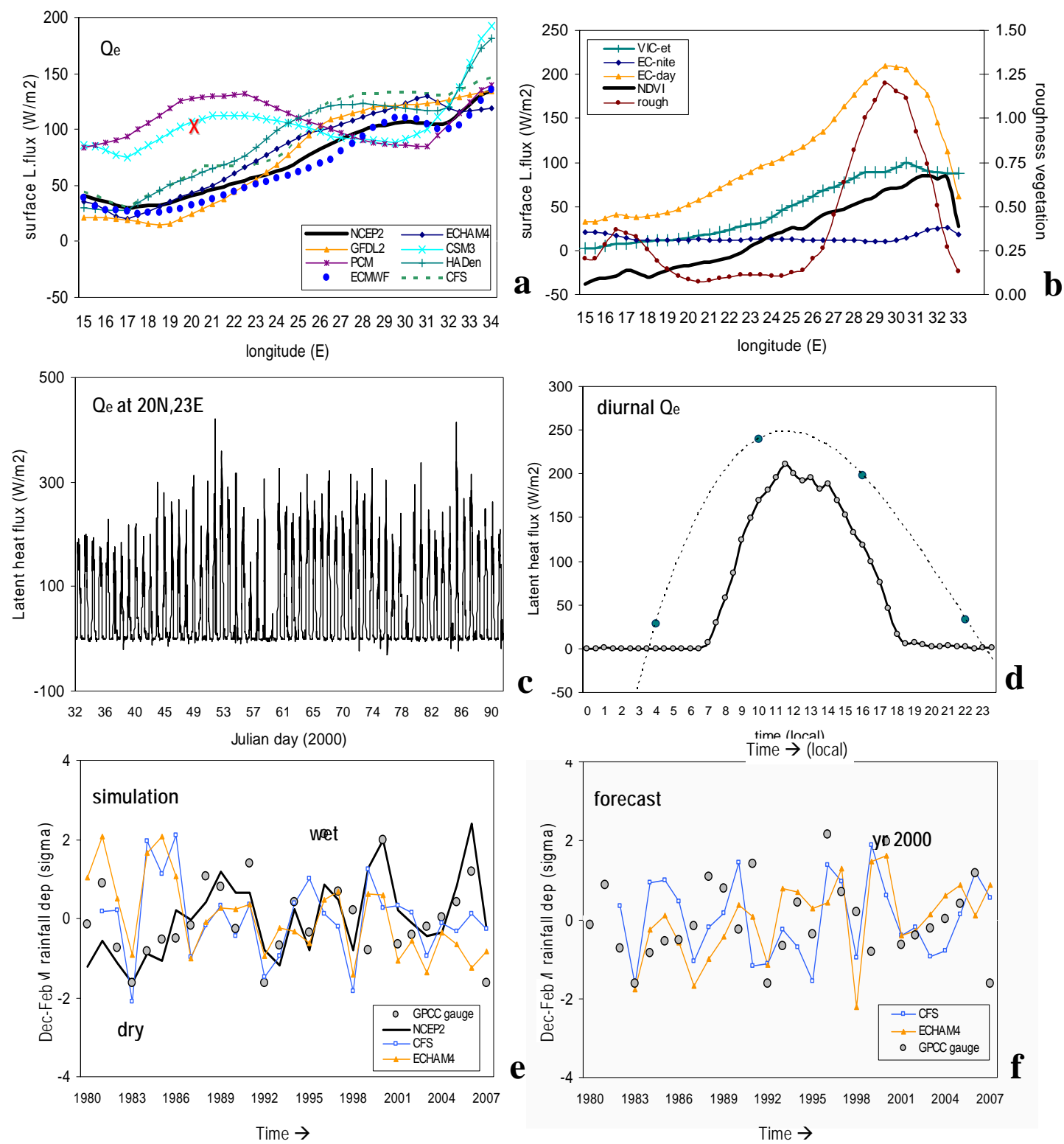

Figure 4

(a) Intercomparison of January mean latent heat flux east-west across South Africa, averaged $25^{\circ}-29^{\circ} S$.

(b) Factors contributing to the January mean east-west gradient: ECMWF day and night latent heat fluxes and roughness, VIC model evapotranspiration and satellite NDVI. (c) Latent heat flux Qe covariance measured at Maun (cf. Fig. 1d) in February-March 2000 and its (d) mean diurnal cycle compared with 6-hourly NCEP (dots). Intercomparison of operational model simulated (e) and 3-month lead forecast (f) December-February rainfall averaged $25^{\circ}-29^{\circ} \mathrm{S}, 25^{\circ}-30^{\circ} \mathrm{E}$ as time series $1980-2007$.

series (Figs. 4e, 4f) reveal that both operational models are too wet in 1984-1986 and too dry in 2000 and 2006 summer seasons. Comparison with the more detailed results of Landman and Beraki (2010) indicate similar levels of performance.

To investigate the diurnal cycle and local feedback between the surface and lower troposphere, AIRS satellite RH profiles are contrasted for a dry (January 2003) and wet (January 2006) summer month. MODIS NDVI and $700 \mathrm{mb}$ wind anomalies (Fig. 5a) indicate the 2003 summer was dominated by subsident westerlies. Green vegetation cover $(>0.6)$ was sparse and confined east of $28^{\circ} \mathrm{E}$. In vertical section, $\mathrm{RH}>40 \%$ extended to $550 \mathrm{mb}$ and was not in contact with the surface over the Kalahari (Figs. $5 \mathrm{~b}$, $5 \mathrm{c}$ ). By contrast, green vegetation extended to $25^{\circ} \mathrm{E}$ in 2006 , even in the Limpopo Valley around $23^{\circ} \mathrm{S}$. Easterly wind anomalies exhibited a rising component over the eastern mountains, and the layer with RH $>40 \%$ reached $500 \mathrm{mb}$. At $700 \mathrm{mb}$ RH exceeded $70 \%$ over the Kalahari $\left(20^{\circ}-25^{\circ} \mathrm{E}\right)$. The moist layer in 2006 sloped according to the underlying surface: upward to the east, while the 2003 structure was tilted up to the west and $~ 20 \%$ drier. The moist layer was shallow in 2003 and remained near the eastern mountains even during daytime heating. In contrast the moist layer in 2006 extended $2 \mathrm{~km}$ above the eastern mountains, and anomalous easterly flow provided lift so that rainfall over the maize belt doubled. The NCEP2 mean latent heat flux over the maize belt in January 2003 was $83 \mathrm{~W} / \mathrm{m}^{2}$ in contrast to $114 \mathrm{~W} / \mathrm{m}^{2}$ in January 2006.

Synoptic changes in winds are driven by the eastward passage of tropical-temperate troughs: in one phase moisture 

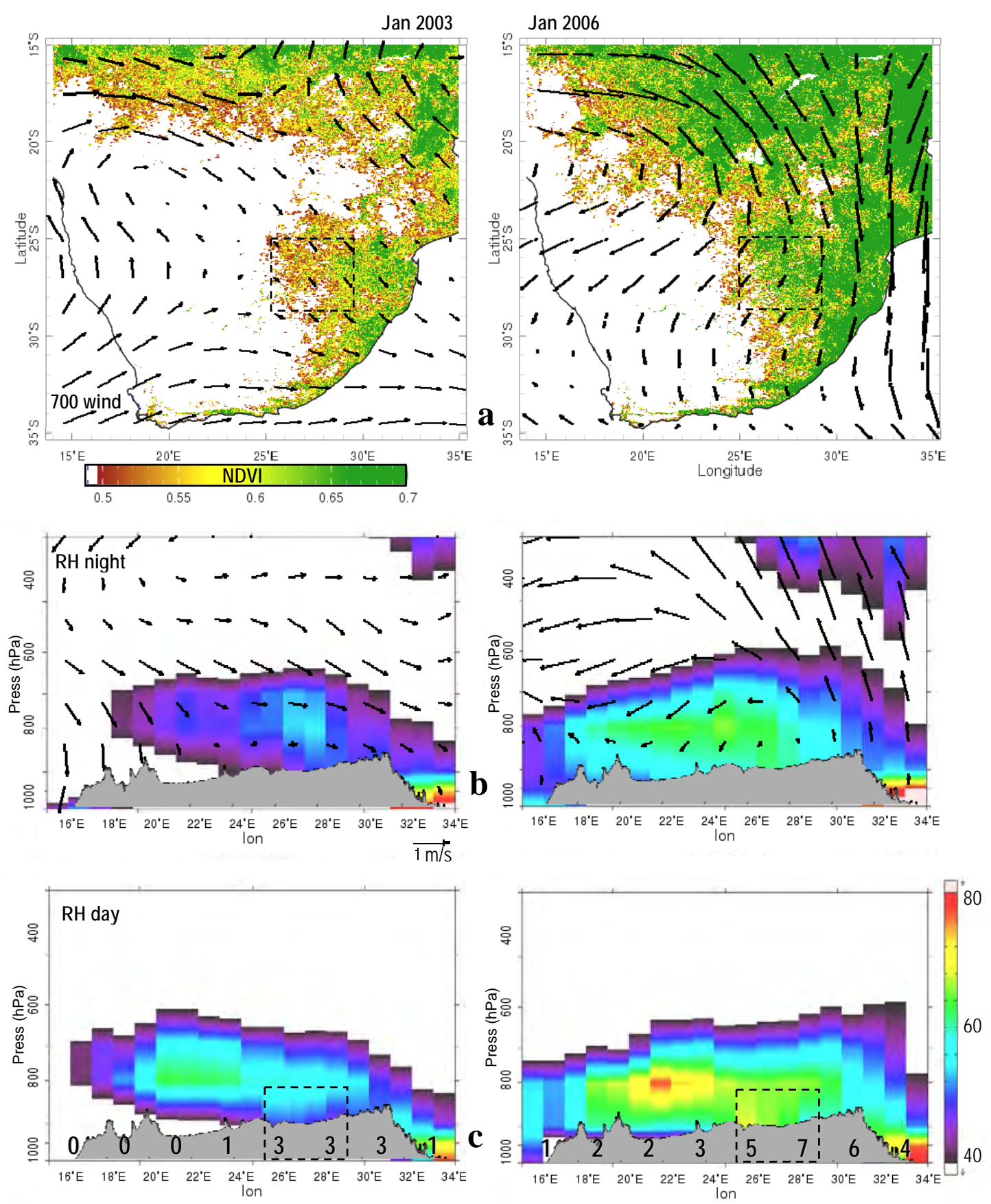

Figure 5

Comparison of dry (left, January 2003) and wet (right, January 2006) summer months: (a) NDVI and NCEP $700 \mathrm{mb}$ wind anomalies, (b) vertical section of AIRS satellite 01:00 relative humidity (\%) and diurnal-average zonal and vertical wind anomalies, (c) vertical section of AIRS $13 \mathrm{hOO}$ relative humidity averaged $25^{\circ}-29^{\circ} \mathrm{S}$ with GPCP rainfall listed ( $\mathrm{mm} /$ day rounded). Colour bars, vector scale, maize box and terrain profiles are given. Vertical motion in (b) exaggerated 100-fold.

is pumped westward onto the plateau; in another phase hot dry Kalahari air spreads eastward. This rhythm is studied using 8-day MODIS day-time land surface temperatures, and smoothed daily NCEP $700 \mathrm{mb}$ winds and GPCP rainfall plotted as hovmollers for the two contrasting summers. Land surface temperatures $>45^{\circ} \mathrm{C}$ spread across central South Africa in 2002-03, but were confined to the desert zone west of $23^{\circ} \mathrm{E}$ in 2005-06 (Fig 6a). The maize belt in January showed significant contrasts in 2002-03: hot spells continued under the influence of subsident westerly winds and infrequent rainfall $>4 \mathrm{~mm} /$ day
(Fig. 6b). In 2005-06 hot spells diminished after December, and cool conditions prevailed with weak easterlies and rising motion. Numerous rain events in excess of $12 \mathrm{~mm}$ /day spread across the Kalahari $\left(20^{\circ}-25^{\circ} \mathrm{E}\right)$ in early 2006 . The synoptic rhythm was more rapid in 2005-06 (12 events), but slower in 2002-03 (9 events).

Predicted long-term trends are briefly examined to determine the extent of model consensus. Projected time series from the various CMIP-3 GCM simulations are illustrated in Figs. $7 \mathrm{a}$ and $7 \mathrm{~b}$ for soil moisture and the zonal overturning 

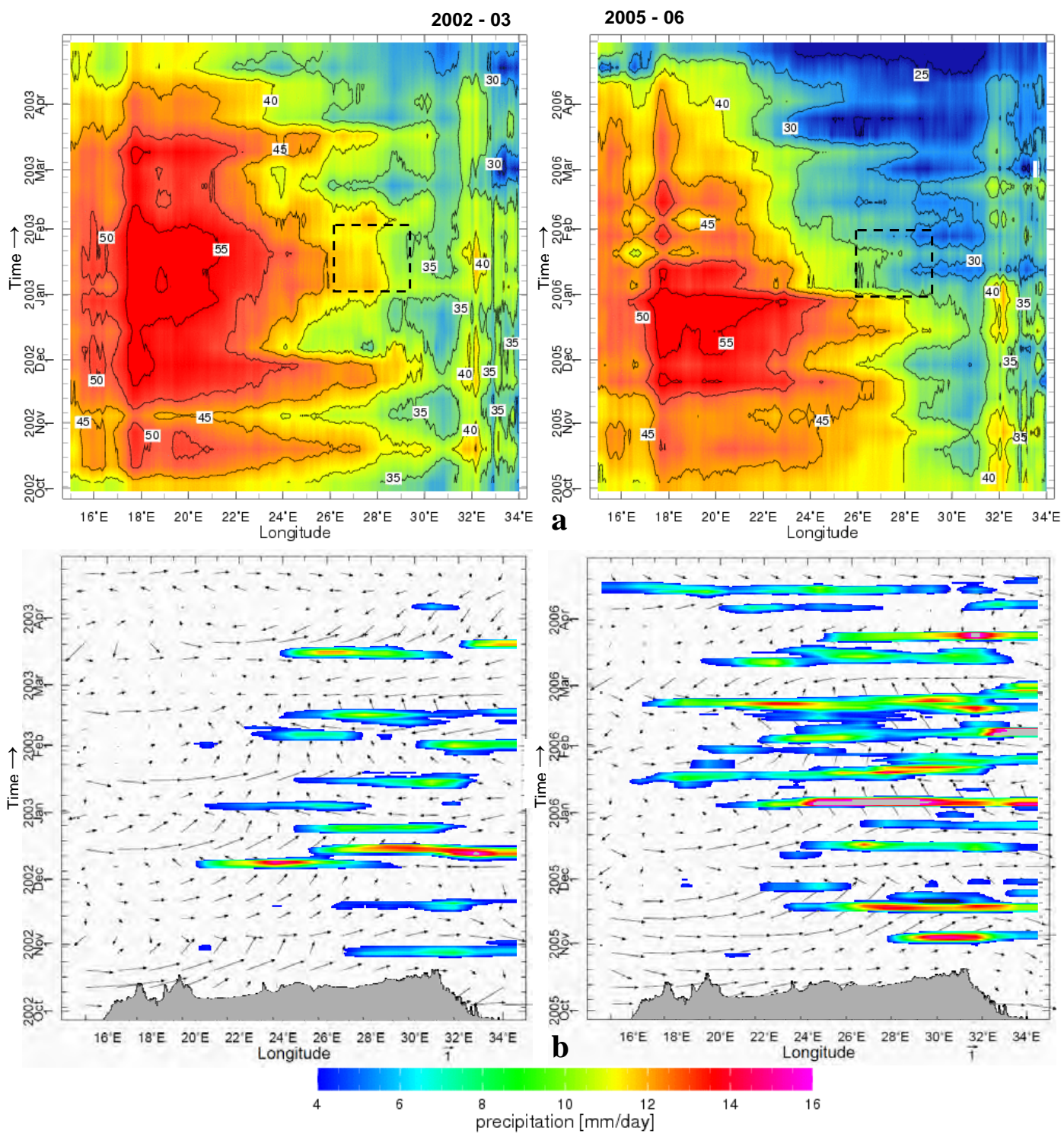

Figure 6

Comparison of dry (left, Oct 2002-Apr 2003) and wet (right, Oct 2005-Apr 2006) season hovmoller plots averaged $25^{\circ}-29^{\circ} \mathrm{S}$ : (a) 8-day MODIS day-time land surface temperatures, (b) smoothed daily NCEP $700 \mathrm{mb}$ zonal wind and vertical motion (vector scale $\mathrm{m} / \mathrm{s}$ ), and GPCP rainfall with values $<4 \mathrm{~mm} /$ day clear. Dashed box in (a) is maize belt in January, terrain profile given in (b).

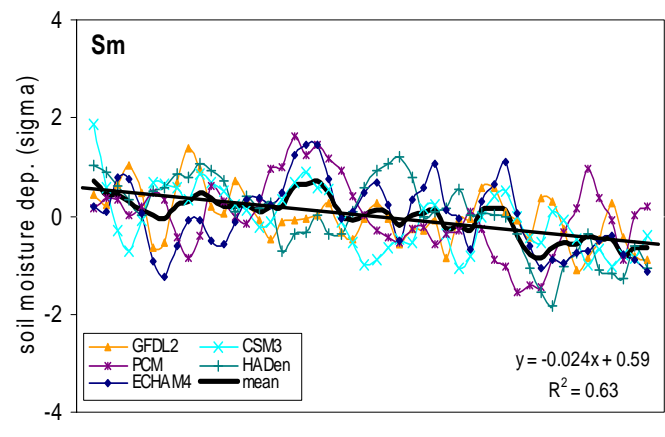

2001200620112016202120262031203620412046

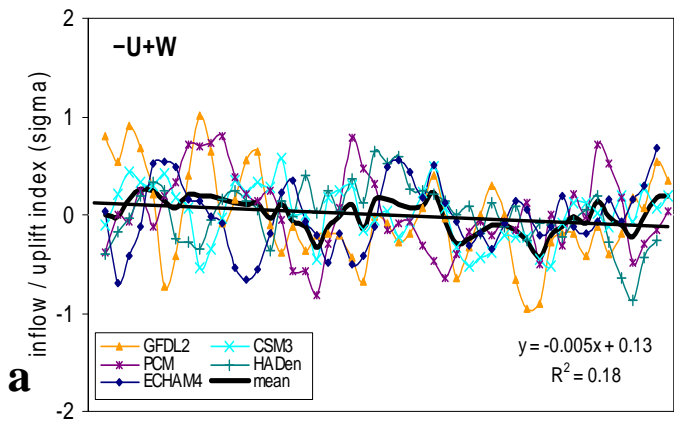

2001200620112016202120262031203620412046

Figure 7

(a) Intercomparison of soil moisture projections for the South Africa maize area, based on the CMIP-3 A1B scenario. Linear trend fit to multi-model mean indicates a steady decline. (b) Same intercomparison but for December-February inflow/uplift circulation index comprised of -U850+W600. 
circulation. These are based on the A1B scenario up to 2050, and intercomparisons are made using standardised departures (value-mean/standard deviation). Soil moisture shows a significant and steady decline in all 6 models of $\sim 1 \sigma$. The linear trend fit is $63 \%$ for the multi-model mean. The CMIP-3 models exhibit out-of-phase inter-annual variability, as expected in such a generic simulation. The projected decline in soil moisture owes more to increased evaporation than reduced precipitation, according to a breakdown of components. A similar outcome is found by Muller (2009) wherein a projected decline in crop-yield over southern Africa is related to CMIP-3 modelsimulated moisture deficits. The zonal overturning circulation index (comprised of December-February -U850+W600 averaged over the maize belt) has a declining trend, but large inter-annual and inter-model variability is found. The linear trend fit for the CMIP-3 multi-model mean is $18 \%$ (Fig. $7 b$ ). The low-level easterly inflow and uplift may diminish, but not at the rate of soil moisture. Thus the predicted desiccation of South Africa's maize belt may derive from local surface and mixed-layer forcing, and not necessarily from changes in the regional circulation.

\section{Conclusions}

This study has compared reanalysis and model products for their ability to represent the east-west gradient of climate over South Africa in the satellite era, with a focus on key features: RH and zonal circulation structure, the annual cycle of rainfall, and latent heat fluxes. All of the CMIP-3 GCM considered have a wet bias over the eastern mountains that extends westward across the maize area, but in 2 cases (CSM3, PCM) high rainfall is erroneously simulated over the Kalahari. The moist layer depth is affected by:

- How much humid SW Indian Ocean air is drawn from the east

- The rate of evapotranspiration (Qe) over the eastern mountains

- The disposition of vertical uplift in the continent-heated air

These complex interactions are adequately represented in the CMIP-3 generation of GCM, even though the vegetation is static. Inter-annual variability was briefly studied and 2 operational ensemble models (CFS and ECHAM4) forecast the summer rainfall with positive correlation compared to observed (GPCP). The 5 generic CMIP-3 models evaluated project a drying trend in the maize area over the period 2000-2050, using the A1B scenario. This trend is only partially accounted for by changes in the regional zonal overturning circulation. Hence the desiccation may be driven by local surface and mixed layer forcing, and increased evaporation from higher surface temperatures. Representation of the diurnal cycle of evapotranspiration was suggested to be important for modelling the east-west gradient in climate (Tadross et al., 2006). Given these insights, it is recommended that the regional observing system be enhanced for measurements of surface and mixed layer moisture fluxes, using an east-west line of flux towers and routine aircraft measurements of moisture covariance (Jury et al., 1997b) in an intensive field campaign that could form part of an ongoing effort by the South African Weather Service. Land-use managers can promote the retention of soil moisture and vegetation cover through crop mulching, recovering unproductive areas, limiting grazing, etc.; so that South Africa can continue as a food-exporting nation.

\section{References}

ADLER RF, HUFFMAN GJ, CHANG A, FERRARO R, XIE PP, JANOWIAK J, RUDOLF B, SCHNEIDER U, CURTIS S, BOLVIN D, GRUBER A, SUSSKIND J, ARKIN P and NELKIN E (2003) The Version-2 Global Precipitation Climatology Project (GPCP) Monthly Precipitation Analysis (1979-Present). J. Hydrometeorol. 4 1147-1167.

ATLAS R, WOLFSON N and TERRY J (1993) The effect of SST and soil moisture anomalies on GL model simulation of the 1988 U.S. summer drought. J. Clim. 6 2034-2048.

BARCLAY JJ, JURY MR and LANDMAN W (1993) Climatological and structural differences between wet and dry troughs over southern Africa in the early summer. Meteorol. Atmos. Phys. 51 41-54.

BARNSTON AG, MASON SJ, GODDARD L, DEWITT DG and ZEBIAK SE (2003) Multimodel Ensembling in Seasonal Climate Forecasting at IRI. Bull. Amer. Meteorol. Soc. 84 1783-1796.

CHANG C-Y, CARTON JA, GRODSKY SA and NIGAM S (2007) Seasonal climate of the tropical Atlantic sector in the NCAR Community Climate System Model 3: Error structure and probable causes of errors. J. Clim. 20 1053-1070.

CHIKOORE H and JURY MR (2010) Intra-seasonal variability of satellite derived rainfall and vegetation over southern Africa. Earth Interactions 14 1-26.

CHRISTENSEN JH and CO-AUTHORS (2007) Regional Climate Projections. In: Solomon S, Qin D, Manning M, Chen Z, Marquis M, Averyt KB, Tignor M and Miller HL (eds.). Climate Change 2007: The Physical Science Basis. Contribution of Working Group I to the Fourth Assessment Report of the Intergovernmental Panel on Climate Change. Cambridge University Press, Cambridge and New York. 996 pp.

COLLINS WD and CO-AUTHORS (2006) The Community Climate System Model version 3. J. Clim. 19 2122-2143.

COX PM, BETTS RA, BUNTON CB, ESSERY RLH, ROWNTREE PR and SMITH J (1999) The impact of new land surface physics on the GCM simulation of climate and climate sensitivity. Clim. Dyn. 15 183-203.

DELWORTH TL and MANABE ME (1989) The influence of soil wetness on near-surface atmospheric variability. J. Clim. 2 1447-1462.

DELWORTH TL and CO-AUTHORS (2006) GFDL's CM2 global coupled climate models. Part 1: Formulation and simulation characteristics. J. Clim. 19 643-674.

DESER C, CAPOTONDI A, SARAVANAN R and PHILLIPS A (2006) Tropical Pacific and Atlantic climate variability in CCSM3. J. Clim. 19 2451-2481.

ENGELBRECHT FA, LANDMAN WA, ENGELBRECHT CJ, LANDMAN S, BOPAPE MM, ROUX B, MCGREGOR JL and THATCHER M (2009) Multi-scale climate modelling over Southern Africa using a variable-resolution global model. Water SA 37 647-658.

FAN Y and VAN DEN DOOL H (2004) Climate Prediction Center global monthly soil moisture data set at $0.5^{\circ}$ resolution for 1948 to present. J. Geophys. Res. 109 D10102. DOI:10.1029/2003JD004345.

GNANADESIKAN A and CO-AUTHORS (2006) GFDL's CM2 Global coupled climate models, Part 2, baseline ocean simulation. J. Clim. 19 675-697.

GORDON C, COOPER C, SENIOR CA, BANKS HT, GREGORY JM, JOHNS TC, MITCHELL JFB and WOOD RA (2000) The simulation of SST, sea ice extents and ocean heat transports in a version of the Hadley Centre coupled model without flux adjustments. Clim. Dyn. 16 147-168.

GRIFFIES S and CO-AUTHORS (2006) Formulation of an ocean model for global climate simulation. Ocean Sci. 1 45-79.

HACK JJ (1994) Parameterization of moist convection in the National Center for Atmospheric Research Community Climate Model (CCM2). J. Geophys. Res. 99 5551-5568.

HOLTSLAG AM and BOVILLE BA (1993) Local versus non-local boundary-layer diffusion in a global climate model. J. Clim. 6 1825-1842.

HUFFMAN GJ, ADLER RF, BOLVIN DT, GU G, NELKIN EJ, BOWMAN KP, HONG Y, STOCKER EF and WOLFF DB (2007) 
The TRMM multi-satellite precipitation analysis: quasi-global, multi-year, combined-sensor precipitation estimates at fine scale. J. Hydrometeorol. 8 38-55.

HULME M, CONWAY D, JOYCE AM and MULENGA H (1996) A 1961-90 climatology for Africa south of the equator and a comparison of potential evapotranspiration estimates. S. Afr. J. Sci. 92 334-343.

JOHNS T and CO-AUTHORS (2006) The new Hadley Centre climate model HadGEM1: Evaluation of coupled simulations. J. Clim. 19 (7) $1327-1353$.

JURY MR, WEEKS S and GONDWE MP (1997a) Satellite vegetation as an indicator of climate variability over southern Africa. S. Afr. J. Sci. 93 34-38.

JURY MR, ROUAULT M, WEEKS S and SCHORMANN M (1997b) Atmospheric boundary layer fluxes and structure across a land-sea transition zone in southeastern Africa. Bound. Layer Meteorol. 83 311-330.

KANAMITSU M, EBISUZAKI W, WOOLLEN J, YANG SK, HNILO JJ, FIORINO M and POTTER GL (2002) NCEP-DOE AMIP-II Reanalysis (R-2). Bull. Am. Meteorol. Soc. 83 1631-1643.

KIEHL JT, HACK JJ, BONAN GB, BOVILLE BA, WILLIAMSON DL and RASCH PJ (1998) The National Center for Atmospheric Research Community Climate Model: CCM3. J. Clim. 11 1131-1149.

LANDMAN WA and BERAKI A (2010) Multi-model forecast skill for mid-summer rainfall over southern Africa. Int. J. Climatol. DOI: 10.1002/joc. 2273 .

LARGE WG, MCWILLIAMS JC and DONEY SC (1994) Oceanic vertical mixing: A review and a model with a nonlocal boundary layer parameterization. Rev. Geophys. 32 363-403.

LLOYD J, KOLLE O, VEENENDAAL E, ARNETH A and WOLSKI P (2004) SAFARI 2000 Meteorological and Flux Tower Measurements in Maun, Botswana, 2000 Data Set. Oak Ridge National Laboratory Distributed Archive Center, Oak Ridge, Tennessee. DOI:10.3334/ORNLDAAC/760.

LOCK AP, BROWN AR, BUSH MR, MARTIN GM and SMITH RNB (2000) A new boundary layer mixing scheme. Part I: Scheme description and SCM tests. Mon. Weather Rev. 128 3187-3199.

MARTIN RV, WASHINGTON R and DOWNING TE (2000) Seasonal maize forecasting for South Africa and Zimbabwe derived from an agroclimatological model. J. Appl. Meteorol. 39 1473-1479.

MARTIN GM, RINGER MA, POPE VD, JONES A, DEARDEN C and HINTON TJ (2006) The physical properties of the atmosphere in the new Hadley Centre Global Environmental Model, HadGEM1. Part 1: Model description and global climatology. J. Clim. 19 1274-1301.

MASON SJ and JURY MR (1997) Climate change and variability over southern Africa: a reflection on underlying processes. Prog. Phys. Geogr. 21 23-50.

MEEHL GA, COVEY C, MCAVANEY B, LATIF M and STOUFFER RJ (2005) Overview of the coupled model intercomparison project (CMIP). Bull. Am. Meteorol. Soc. 86 89-93.

MEEHL GA, COVEY C, DELWORTH T, LATIF M, MCAVANEY B, MITCHELL JFB, STOUFFER RJ and TAYLOR KE (2007) The WCRP CMIP3 multimodel dataset: A new era in climate change research. Bull. Am. Meteorol. Soc. 88 1383-1394.

MISRA V, DIRMEYER PA and KIRTMAN BP (2002) A comparative study of two land surface schemes in regional climate integrations over South America. J. Geophys. Res. 107 (D20) 8080.
MULLER C (2009) Climate Change Impact on Sub-Saharan Africa: An Overview and Analysis of Scenarios and Models. Deutsches Inst Entwicklungspolitik, Bonn. ISBN: 978-3-88985-451-3.

NAKICENOVIC N and SWART RJ (2000) Emissions Scenarios 2000 - Special Report of the Intergovernmental Panel on Climate Change. Cambridge University Press, Cambridge. 570 pp.

OBERHUBER JM (1993) Simulation of the Atlantic circulation with a coupled sea-ice mixed layer-isopycnal general circulation model. Part I: model description. J. Phys. Oceanogr. 13 808-829.

POVEDA G, JARAMILLO A, GIL MM, QUICENO N and MANTILLA R (2001) Seasonality in ENSO-related precipitation, river discharges, soil moisture, and vegetation index in Colombia. Water Resour. Res. 37 2169-2178.

POVEDA G, MESA OJ, SALAZAR LF, ARIAS PA, MORENO HA, VIEIRA SC, AGUDELO PA, TORO VG and ALVAREZ JF (2005) The diurnal cycle of precipitation in the tropical Andes of Colombia. Mon. Weather Rev. 133 228-240.

POVEDA G and CO-AUTHORS (2006) Modern climate variability in northern South America and southern Mesoamerica. Palaeogeogr. Climatol. Ecol. 234 3-27.

REICHLER T and KIM J (2008) How well do coupled models simulate today's climate? Bull. Am. Meteorol. Soc. 89 303-311.

ROECKNER E, ARPE K, BENGTSSON L, CHRISTOPH M, CLAUSSEN M, DÜMENIL L, ESCH M, GIORGETTA M, SCHLESE U and SCHULZWEIDA U (1996) The atmospheric general circulation model ECHAM-4: model description and simulation of present-day climate. Max-Planck Institute for Meteorology, Report 218, Hamburg, Germany. 90 pp.

SAHA S, NADIGA S, THIAW C and WANG J (2006) The NCEP Climate Forecast System. J. Clim. 19 3483-3517.

SCANLON TM and ALBERTSON JD (2004) SAFARI 2000 Kalahari Transect CO2, Water Vapor, and Heat Flux Wet Season 2000 Data Set. Oak Ridge National Laboratory Distributed Archive Center, Oak Ridge, Tenn. DOI:10.3334/ORNLDAAC/765.

SCHULZE RE, KIKER GA and KUNZ RP (1993) Global climate change and agricultural productivity in southern Africa. Global Environ. Change 3 330-349.

SHEFFIELD J, GOTETI G and WOOD EF (2006) Development of a 50-year high-resolution global dataset of meteorological forcings for land surface modeling. J. Clim. 19 3088-3111.

TADROSS MA, JACK C and HEWITSON B (2005) On RCM-based projections of change in southern African summer climate, Geophys. Res. Lett. 32 23-26.

TADROSS MA, GUTOWSKI WJ, HEWITSON BC, JACK C and NEW M (2006) MM5 simulations of interannual change and the diurnal cycle of southern African regional climate. Theor. Appl. Climatol. 86 63-80.

TAYLOR KE, STOUFFER RJ and MEEHL GA (2012) An overview of CMIP5 and the experiment design. Bull Amer. Meteorol. Soc. 93 485-498.

UPPALA S and CO-AUTHORS (2005) The ERA-40 re-analysis. Q. J. R. Meteorol. Soc. 131 2961-3012.

WASHINGTON WM, WEATHERLY JW, MEEHL GA, SEMTNER AJ, BETTGE TW, CRAIG AP, STRAND WG, ARBLASTER JM, WAYLAND VB, JAMES B and ZHANG Y (2000) Parallel climate model (PCM) control and transient simulations. Clim. Dyn. 16 755-774.

WILSON MF and HENDERSON-SELLERS A (1985) A global archive of land cover and soils data for use in general circulation climate models. Int. J. Climatol. 5 119-143. 
http://dx.doi.org/10.4314/wsa.v38i4.1 Available on website http://www.wrc.org.za

ISSN 0378-4738 (Print) = Water SA Vol. 38 No. 4 July 2012 ISSN 1816-7950 (On-line) = Water SA Vol. 38 No. 4 July 2012 